\title{
The Stela of Ni-Ppy of Abydos
}

\section{Dr. Ahmed Hamdy Abdelmoniem}

\begin{abstract}
:
A limestone stela in Cairo Museum is the subject of this article ${ }^{(*)}$. It bears the no. CG 1579 from the publications of L. Borchardt, Denkmaler des Alten Reiches II, (Ausser den Statuen) im Museum von Kairo, p. 60.

The stela belongs to the true count, gracious of Arm and the sole companion Ni-Pepy. It was found in Abydos in the middle necropolis, probably it might be from his tomb ${ }^{(1)}$.

The stela includes many interesting details regarding its textual, epigraphic and artistic details, it is never fully published before.

\section{Description:}

It is a rectangular stela made of limestone, measures $130 \mathrm{c} . \mathrm{m}$ high, $67 \mathrm{c} . \mathrm{m}$ in width and $14 \mathrm{c} . \mathrm{m}$ in thickness. The stela is fair workmanship, its state of preservation is good with a slight breaking in the lower right side of the stela. There are no traces of colours that can be observed on it, the figure of the stela's owner as well as all the inscriptions are incised ${ }^{(2)}$.

The stela is divided into two main registers, the upper register consists of five horizontal hieroglyphic inscriptions, all the signs are obvious without any shattering, oriented from right to left, a framing line separates these lines apart from each other. While the lower register is divided into two parts, where the left part is larger than the right one, it represents the deceased standing barefooted in the traditional pose with the left leg forward, the deceased's face is destroyed except some details can hardly seen as the nose, lips and the lower part of the ear. His left hand is raised in an addressing posture ${ }^{(3)}$, where the raised hand is stretched straight forward with the thumb spread upwards and the deceased is acting in the rhythm of speech (Dd) ${ }^{(4)}$, where his arm isn't stretched straight forward at shoulder height, the elbow angels it so far that made the hand reaches about shoulder level or little higher. While his right hand extends beside his side. The deceased is depicted wearing a tight knee length kilt $^{(5)}$ with a triangular front projection, the girdle is seen around the waist, a broad collar around the neck with a trapezoidal front part and two beaded wristbands. He is also wearing a shoulder length wig which leaves the ear exposed ${ }^{(6)}$, the sides of the wig show a concave curve and contain long locks ${ }^{(7)}$. The right part of the lower register is smaller than the left one, it consists of two vertical hieroglyphic inscriptions each contains two titles of the deceased, the signs of these lines are oriented from right to left where the left framing line of the inscriptions delineates the two lower parts of the lower register from each other.
\end{abstract}




\section{Text and Translation:}

1- $\int 0$ I I

I anxw tpw tA bAkw miti. $i^{(8)}$

O, you who live upon the earth, servants like me.

$2-$

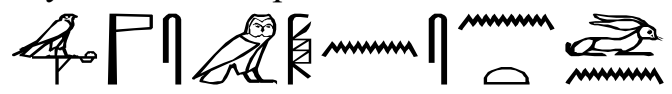

Wnnt.sn (m) Sms nTr

May they excist in the following of the god.

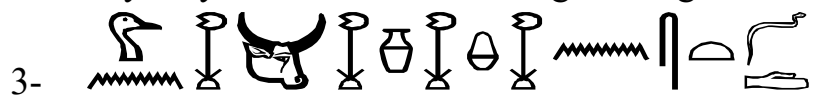

Ddt.sn xA t xA Hnqt xA kAw xA Apdw n

May they say thousand of bread, thousand of beer, thousand of oxen and thousand of fowl to

4-

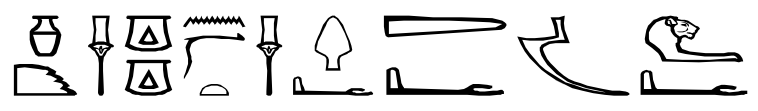

HAty-a mAa imA-a xrp nsty xrp hAts km

True count ${ }^{(9)}$, gracious of arm $^{(10)}$, director of the two thrones ${ }^{(11)}$, controller of the black jar ${ }^{(12)}$.

5-

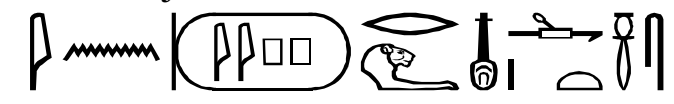

smr-waty iry nfr-HAt Ni-Ppy

Sole companion ${ }^{(13)}$, keeper of the headdress ${ }^{(14)}$, Ni-Ppy

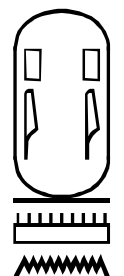

同

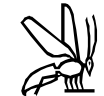

6- תم sHD Hm(w)-nTr Mn-nfr-Ppy xtmty-bity 
inspector of Hm-nTr priests of the pyramid of Pepi $\mathrm{I}^{(15)}$, sealer of the king of lower Egypt ${ }^{(16)}$.

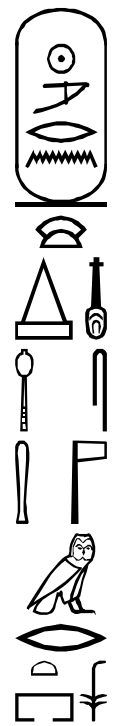

sHD Hm(w)-nTr \#a-nfr-Mr-n-Ra imy-r pr-nswt.

Inspector of $\mathrm{Hm}-\mathrm{nTr}$ priests of the pyramid "the perfection - of - Merenre appears - in Glory" ${ }^{\text {(17) }}$, overseer of the king's domain ${ }^{(18)}$.

\section{The Commentary:}

(1.) The name of the stela's owner was mentioned by Ranke in his PN, where he translated it as "the one belonging to king Pepy"(19), Kuraszkiewicz mentioned that the name Ni-Ppy was attested three times in the Old Kingdom, once in Abydos - on the current stela - as well as twice in the Memphite Necropolis ${ }^{(20)}$. It is worth mentioning that at the end of the Old Kingdom the names associated with the cartouches of the king (his name) were familiar during the sixth dynasty ${ }^{(21)}$.

\section{The stela bears ten titles for the deceased, as follows:}

(2.1.) HAty-a mAa: The title is translated as "true count" ${ }^{(22)}$, most probably this title appeared at the end of the fifth dynasty by the reign of Unis where it was held by his vizier $\mathrm{SnDm}$-ib / $\mathrm{MHi}^{(23)}$ and continued in use till the end of the Old Kingdom ${ }^{(24)}$.

The addition of the adjective mAa after titles was discussed by many scholars, Both $\mathrm{Wb}$ and Edgerton believed that it refers that the office was really practiced in reality and wasn't honorific ${ }^{(25)}$, Kanawati added that such addition shows a degree of importance, uniqueness or might be superiority for its holders ${ }^{(26)}$, while Gunn, Nims and James suggested that it doesn't show any significant importance to an office or to its holders ${ }^{(27)}$, Fischer agreed with that opinion suggesting that the addition of the adjective mAa after titles except imy-r Smaw (overseer of Upper Egypt) is of little importance $^{(28)}$. 


\section{The Stela of Ni-Ppy of Abydos}

(2.2) imA-a: It is translated as "gracious of arm" (29), the title might have appeared for the first time in the third dynasty ${ }^{(30)}$ and appeared everynow and then in the Fourth and Fifth dynasties ${ }^{(31)}$, while during the beginnings of the Sixth dynasty it was a notable title in the titularies of the viziers of that era ${ }^{(32)}$.

The title was held in the Old Kingdom - according to a table presented by Strudwick - by twenty officials, seventeen of them were buried in the Memphite necropolis, twelve of them were viziers ${ }^{(33)}$, while only three officials from the provinces, Ni-Ppy the owner of the current stela from Abydos and l'bi of Deir el Gebrâwi ${ }^{(34)}$.

The title consists of two parts, the sign $\overbrace{}^{(35)}$ which means "gracious" or "charm" or "favourite"(36), while the other is ${ }^{(37)}$ which means assistant when associated with "offices" or "deities"(38).

For this title, it is worth commenting that most of its holders were responsible for the royal documents ${ }^{(39)}$, Strudwick noted that at the sixth dynasty this title was mainly held by the viziers ${ }^{(40)}$, Baud agreed with that opinion and added that this title was an award for the viziers ${ }^{(41)}$, this note made Y De Preter suggested that Ni-Ppy was a vizier ${ }^{(42)}$, although he never held the vizierate title tAyty-sAb-TAty.

For the function of that title, an official called SSm-nfr IV ${ }^{(43)}$ listed his titles as follows:

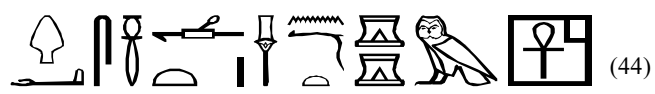

imA-a Smr-waty xrp nsty m pr-anx

"gracious of arm, Sole companion, director of the two thrones in the mansion of life" ${ }^{\text {(45). }}$.

The order of these titles may indicate that they were in the same level of significance, it also relates a relation between xrp nsty and the Hwt-anx, the first is a title associated with the palace ${ }^{(46)}$ and the Hwt-anx was part of the royal palace where the sovereign lived and had his being ${ }^{(47)}$.

It is also worth to mention that the Hwt-anx is known from the Famine stela of Sehel as a place where books can be reviewed, read and consulted ${ }^{(48)}$, which is the same function of the pr-anx ${ }^{(49)}$, this latter had a direct relationship with the current title appeared in a Middle Kingdom title as following:

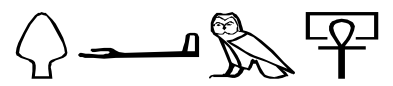




\section{imA-a m pr-anx}

Gracious of Arm in the House of life

So, one can conclude that the three titles imA-a, Smr-waty and the xrp nsty had a permanent link with each other due to their direct relationship with the sovereign ${ }^{(51)}$, if one adds that Ni-Ppy was also imy-r pr-nsw, so he was a very close official to the king and consequently the office of imA-a might be a scribal function in the palace or at least a profession in the royal palace.

(2.3.) xrp nsty: it means "director of the two thrones" ${ }^{\text {"(52) }}$, according to Gardiner that office was connected with the throne on which the king sat while eating and the allusion here of two thrones, this duality refers to the two seats of king and queen who will take their meals together with each other like any other man and his wife ${ }^{(53)}$. Gardiner suggests that the dual designations of Upper and Lower Egypt should be taken with caution with the current office ${ }^{(54)}$, Helck agreed with Gardiner believing that it was a middle level rank title for independent servants of the palace ${ }^{(55)}$.

(2.4.) xrp hAts km: it means "Controller of the black jar" ${ }^{\text {"(56) }}$, this title was first attested in the fourth dynasty by DwA-n-Ra who is dated by the end of the fourth dynasty ${ }^{(57)}$ and that title continued till the end of the Old Kingdom ${ }^{(58)}$.

The title in question didn't appear only in the Memphite necropolis, but it was also attested in the provinces as it is found in El-Hawawish ${ }^{(59)}$. Gardiner mentioned that the current title was attested frequently with the previous title xrp nsty ${ }^{(60)}$, As for the black jar, it is most probably the jar of wine where the wine was put in it ${ }^{(61)}$, Junker connected that title with the cult of Hathor ${ }^{(62)}$, since Hathor was the goddess of wine and music $^{(63)}$.

In fact, Gardiner believed also that these titles was connected with the royal banquet ${ }^{(64)}$, thus proved the usual appearance of both titles xrp nsty and xrp hAts km together with each other, it is most probably that the holders of the title xrp hAts $\mathrm{km}$ were responsible for pouring the wine to the king and queen during taking their meals.

(2.5) Smr-waty: it means the "Sole Companion" (65), this title might have appeared for the first time in the reign of king Khufu by @m-Iwnw ${ }^{(66)}$, the son of the vizier NfrMAat of Medum ${ }^{(67)}$.

The office was comman and characteristic of the late of the Old Kingdom in the Memphite necropolis and the provinces as well ${ }^{(68)}$, there is an allusion from the royal decrees that the holders of that title might have served as royal envoys ${ }^{(69)}$, which presents two indications, the first is that the Smr-waty wasn't a honorific title ${ }^{(70)}$, but its holders had responsibilities to carry out for the sovereign, while the second is that 


\section{The Stela of Ni-Ppy of Abydos}

the revenue of this office was good enough to have an inscribed stela or probably due to their close connection with the sovereign who might have allowed them to have a private stela.

(2.6) Iry Nfr-HAt: it means "keeper of the headdress" ${ }^{\text {(71) }}$, it is worth to note that the word Nfr-HAt never attested with the hair determinative ${ }^{(72)}$, which makes it difficult to assume that it refers to a wig ${ }^{(73)}$. Wb and Faulkner refered that Nfr-HAt means diadem $^{(74)}$, which means a jeweled crown or headband worn as a symbol of sovereignty ${ }^{(75)}$. So it was a headdress or a fillet ornamented with jewels worn by the kings $^{(76)}$.

The holders of that title had direct connection with the living king in his palace, this connection is proved by the titles: iry nfr-HAt $m$ st nt nswt (keeper of the headdress in the place of the king) ${ }^{(77)}$ also iry nfr-HAt m sXkr @ (keeper of the headdress who adorns Horus i.e. the king) ${ }^{(78)}$. Both titles indicate the responsibility of the iry nfr-HAt in ornamenting and dressing the sovereign.

No doubt that the iry nfr-HAt was a Memphite title due to the direct relationship with the king, but it was attested in the sixth dynasty four times in the provinces, the first is Ni-Ppy the owner of the current stela and three other officials all of them are dated by the reign of Pepy II, @aw from Abydos ${ }^{(79)}, \mathrm{KAi}-\mathrm{Hb} /{ }^{*}$ ti from Akhmim $^{(80)}$ and Ppy-anx-Hry-ib from (Meir) ${ }^{(81)}$. It is worth to note that the last three officials as Ni-Ppy had started their own careers at Memphis as reflected from their titles $^{(82)}$.

(2.7.) sHD Hm(w)-nTr Mn-nfr-Ppy(83): It means "inspector of Hm-nTr priests of the pyramid of Pepi I"(84).

(2.8.) sHD Hm(w)-nTr \#a-nfr-Mr-n-Ra ${ }^{(85)}$ : inspector of Hm-nTr priests of the pyramid of Merenre.

The Hm-nTr priests were usually worked in a phyle system with shift rotations, this system was usually maintained by endowments left by the king or the tomb owner in case of private tombs for themselves, this explains the flourishing of the system in the early part of the sixth dynasty and its collapse at the end of that dynasty ${ }^{(86)}$.

The stela's owner from those titles was associated with the cult temples of both Pepy I and Merenre I, his association with such royal cults probably indicates that he was contemporary to them or at least to the latter.

The temple personnel included Hm-nTr priests, wab priests, Xry-Hbt lector priests, xnty-S farmers and Dt servants, among others, who performed different 
aspects of the cult and received different shares of the offerings, they were headed by sHD Hm(w)-nTr (inspector of $\mathrm{Hm}-\mathrm{nTr}$ priests) ${ }^{(87)}$, who was Ni-Ppy in our case. The title $\mathrm{Hm}$-nTr priest frequently alternates with the title wab priest one or more lector priests were permanently assigned to each pyramid temple to recite rituals during the daily activities and the monthly services as well ${ }^{(88)}$.

Muhs suggested that all these personnel only served one month in ten and thus they were able to serve in multiple mortuary cults or to engage in other economic activities $^{(89)}$, which appeared with Ni-ppy who was SHD Hm-nTr priest in both mortuary cult temples of both kings Pepy I and Merenre I.

(2.9.) xtmty-bity: it means "Sealar of the king of Lower Egypt" "(90), Fischer noted that the reading of such title is xtmty-bity not sDAwty-bity ${ }^{(91)}$.

The title was known since the first dynasty, it was held by Hemaka ${ }^{(92)}$, Anyways, this title was a very common high status Old Kingdom title, it appeared frequently during the fourth dynasty and from the sixth dynasty onwards, but it was less sporadic in the fifth dynasty ${ }^{(93)}$.

Uphill recognized that this title indicates an office hardly a rank and it was spread much more widely than to be held by an official or two at the same time, this was proved by the numerous number of holders of that office in all periods ${ }^{(94)}$.

As a matter of fact that the main reason for the spread of that title; was that the king as well as the state required large stores and magazines for food and all kinds of raw materials in the provinces throughout Egypt, the security of this stores was moved to the local chief ${ }^{(95)}$, consequently the services of the seal bearer was always required ${ }^{(96)}$, this was proved by Murray's Index where the officials with the rank HAtya have the rank sDAwty-bity (xtmty-bity) ${ }^{(97)}$, also Weni's list of the army ${ }^{(98)}$, he was entrusted with the seal bearers of the king of Lower Egypt

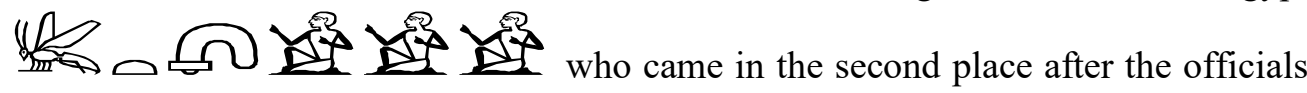
with the title a mAa, so he was responsible for the stores and the magazines of food as well as all kinds of raw materials in Abydos, where the stela was discovered.

(2.10.) Imy-r pr-nswt: it means "Overseer of the King's domain"(100), Perhaps its appearance was duc to the need of the sovereign to assign one of his civil servants to manage and direct the royal palace ${ }^{(101)}$, the title was attested in the Memphite necropolis and the provinces as well ${ }^{(102)}$. 


\section{The Stela of Ni-Ppy of Abydos}

From the previous titles, it is clear that Ni-Ppy served in the residence for a period of time where he was serving in the royal palace and he was in a direct contact with the king depending on the titles (2.2.), (2.3.), (2.4.), (2.5.), (2.6.), (2.10.) also the titles (2.7.) and (2.8.) support this result that Ni-Ppy was an official in the mortuary cults of both Pepy I and Merenre I, then after a time Ni-Ppy moved to the Eighth Nome of Upper Egypt (Abydos) where he held the title HAty-a mAa and consequently he held the title xtmty-bity as a responsible for the stores of that nome since Abydos was in a close connection with the Memphite residence in the Old Kingdom as the center of royal administration in Upper Egypt during the Old Kingdom ${ }^{(103)}$.

\section{Dating:}

The stela beard some textual, iconographical and epigraphical aspects of dating which are:

(1) The two titles held by the deceased sHD Hm(w)-nTr Mn-nfr-Ppy and sHD $\mathrm{Hm}(\mathrm{w})-\mathrm{nTr} \# \mathrm{Aa}-\mathrm{nfr}-\mathrm{Mr}-\mathrm{n}$ - Ra indicate that he was serving as a Hm-priest in the mortuary cult of both kings, which may indicate that he was contemporary to both of them or at least the last king Merenre I, this point of view was advocated by Baer ${ }^{(104)}$. It is also probably that it is not earlier than the Middle Kingdom that one finds that office associated with a god's temple ${ }^{(105)}$.

(2) In the first horizontal line appears an addressing to the living, the request for the passer - by to read the offerings as the lector priest does is unusual, but it reminds as of some of the tasks which the lector priest did for the tomb owner ${ }^{(106)}$, it also calls to mind the direct request made by the tomb owner to lector priests in this sort of text ${ }^{(107)}$. But it is worth noting that by the end of Pepi's I reign, the formula of "Call to the living" completely eliminates the "Call to Specialists" i.e. the lector priests, as well the threatening texts - which were both known before the sixth dynasty - as a result the address to visitors falls into disuse ${ }^{(108)}$.

Sainte Fare Garnot noted that the formula of "addressing to the living" passed by an evolution in the sixth dynasty, this evolution found its equilibrium point under Merenre I before continuing under Pepy II, where two periods can be distinguished in the history of the "addressing to the living". Under the first reigns of the sixth dynasty, The first begins with the advent of Teti and ends around the middle of Pepi's I reign, while the last years of Pepi I and the reign of Merenre provided the framework for the second ${ }^{(109)}$, and at that time calling or addressing to the living eliminates the addressing to specialists and threatening texts and the recitation of so-called food prayers replaces from then - the end of Pepi I and the reign of Merenre - the gift of the real offerings in the statement of the expected services ${ }^{(110)}$. 
That was also appeared on the current stela where the "addressing to the living" is not accompanied by duties to the lector priests (specialists) and was also followed by the food prayer (xA t xA Hnqt ...) which indicate that this stela might be dated by the last years of Pepi I but from the title no. (8) the deceased was associated with the mortuary cult of king Merenre I, so the formula and the titles too proved that the deceased was contemporary to Pepi I and Merenre I or at least the last king where also the current formula reached its peck and continued in its new form in the reign of Pepi II.

(3) The deceased appears standing in a posture of "addressing"(111), this posture is known since the early fifth dynasty ${ }^{(112)}$, but it became frequent in the sixth dynasty $^{(113)}$.

(4) The stela contains many artistic aspects which is characteristic of the second Old Kingdom style ${ }^{(114)}$ : The type of the wig worn by the deceased ${ }^{(115)}$, the broad collar ${ }^{(116)}$, the position of the bottom of the ear on a line with the bottom of the nose ${ }^{(117)}$ and the setting of the ears vertically without alignment ${ }^{(118)}$.

(5) The researcher mentioned that the stela's owner name was Ni-Ppy this name was attested three times in the Old Kingdom, two of them in the Memphite necropolis who were buried in the vicinity of Pepy $\mathrm{II}^{(119)}$, while the third one was the stela's owner, which may indicate that our stela's owner might be contemporary to the other two Memphite officials who bore the same name.

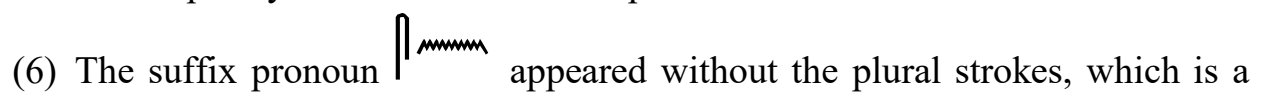
common feature till the twelfth dynasty ${ }^{(120)}$.

(7) The title sHD Hmw-nTr of a royal pyramid complex is not common in provinces after the middle of the sixth dynasty ${ }^{(121)}$.

\section{Conclusion:}

(1) Ni-Ppy was a Memphite official, served in the royal palace and was very close to the kings, at the same time he served in the mortuary cults of the kings in Memphis. After a long life in Memphis, he might be appointed due to his loyality as a "count" - according to his first title - probably at Abydos Where the Stela was discovered.

(2) From the previous dating features, it is obvious that the stela is a sixth dynasty stela, but according to the type of the wig, the broad collar worn by its owner, the position of the ear on a line with the bottom of the nose and the depictation of the ear vertically (remark 4), the stela might be dated from the reign of Pepy I to the end of the Old Kingdom, but since the name of the deceased ( $\mathrm{Ni}$ Ppy) was attested twice in the Memphite necropolis both were buried in the vicinity of Pepy II's pyramid complex (remark 5), also the formula of "addressing the living" took its current form from the last years of Pepy I, flourished in the reign of Merenre I and continued in Pepy's II reign (remark 


\section{The Stela of Ni-Ppy of Abydos}

2), as well as the appearance of the title sHD Hmw-nTr of a royal pyramid, this title wasn't common in provinces after the middle of the sixth dynasty (remark 7), also the fact that the title iry nfr-HAt was held by three other provincial officials all of them were dated by the early reign of Pepy II (the commentary 2.6.), so the stela isn't earlier than the reign of Pepy I and not later than the middle of the sixth dynasty but according to the two titles held by the deceased in the mortuary cults of both sovereigns Pepy I and Merenre 
Dr. Ahmed Hamdy Abdelmoniem

I. I tend to date the stela by the reign of Merenre I to the early years of Pepy

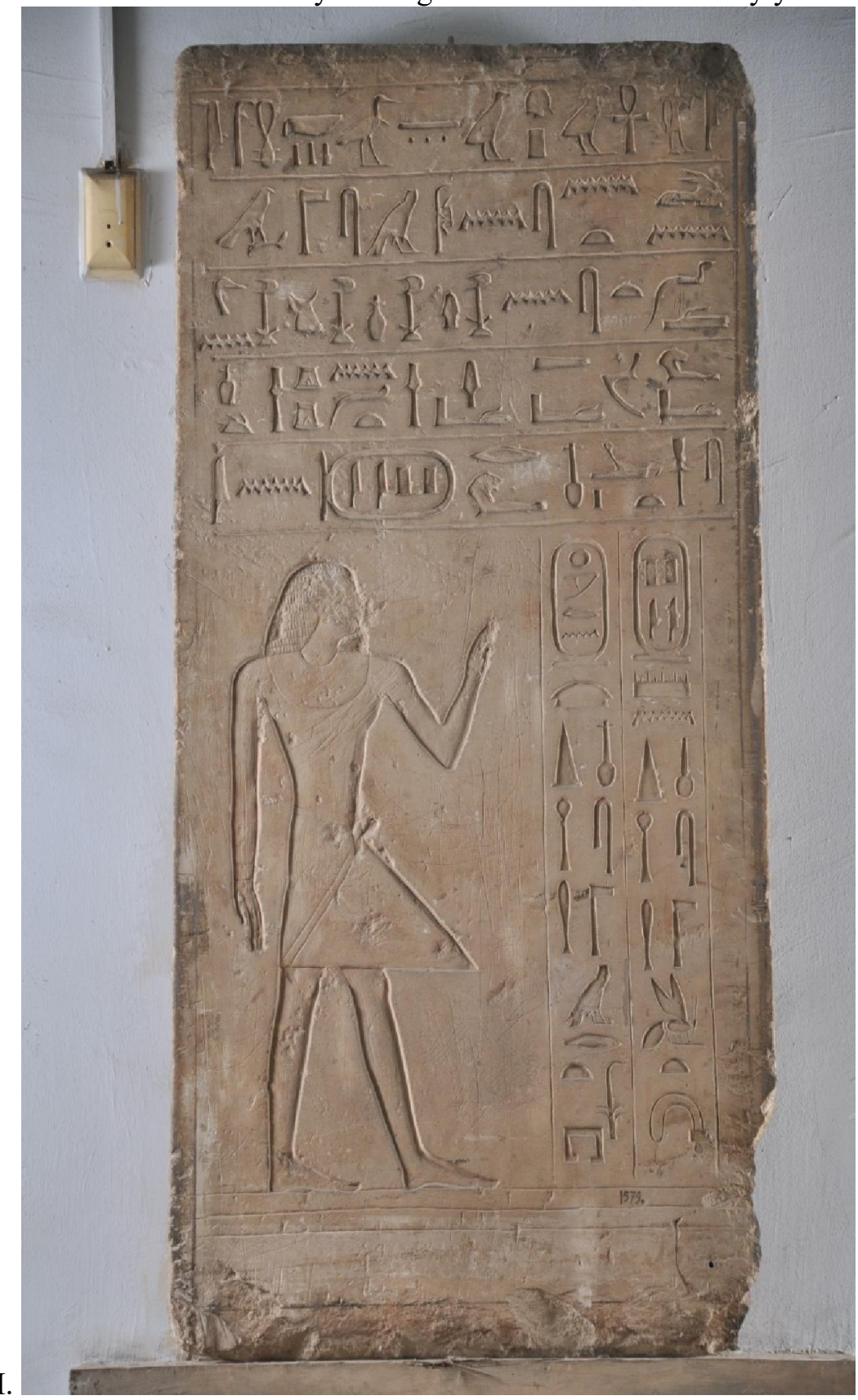


The Stela of Ni-Ppy of Abydos

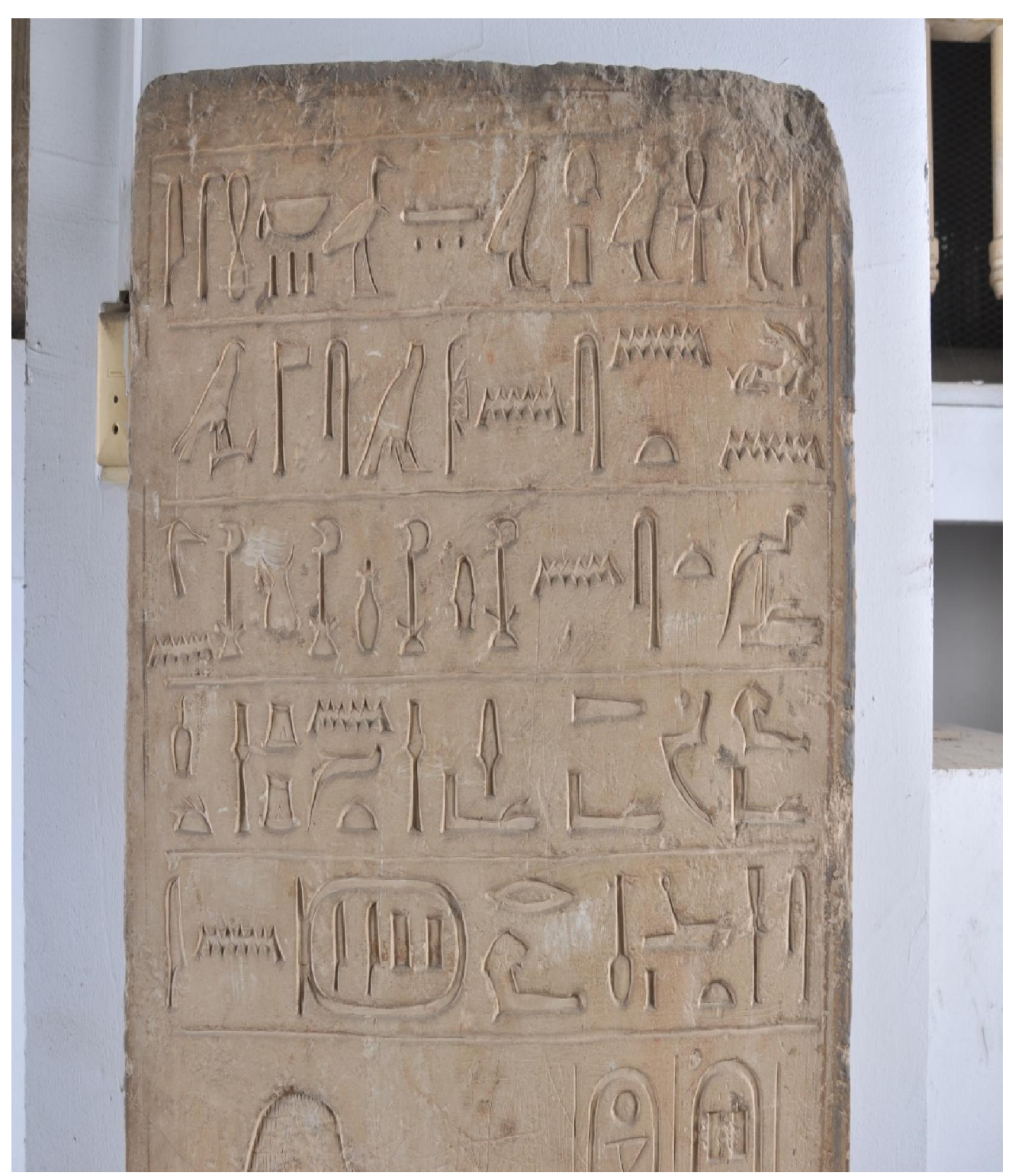


Dr. Ahmed Hamdy Abdelmoniem

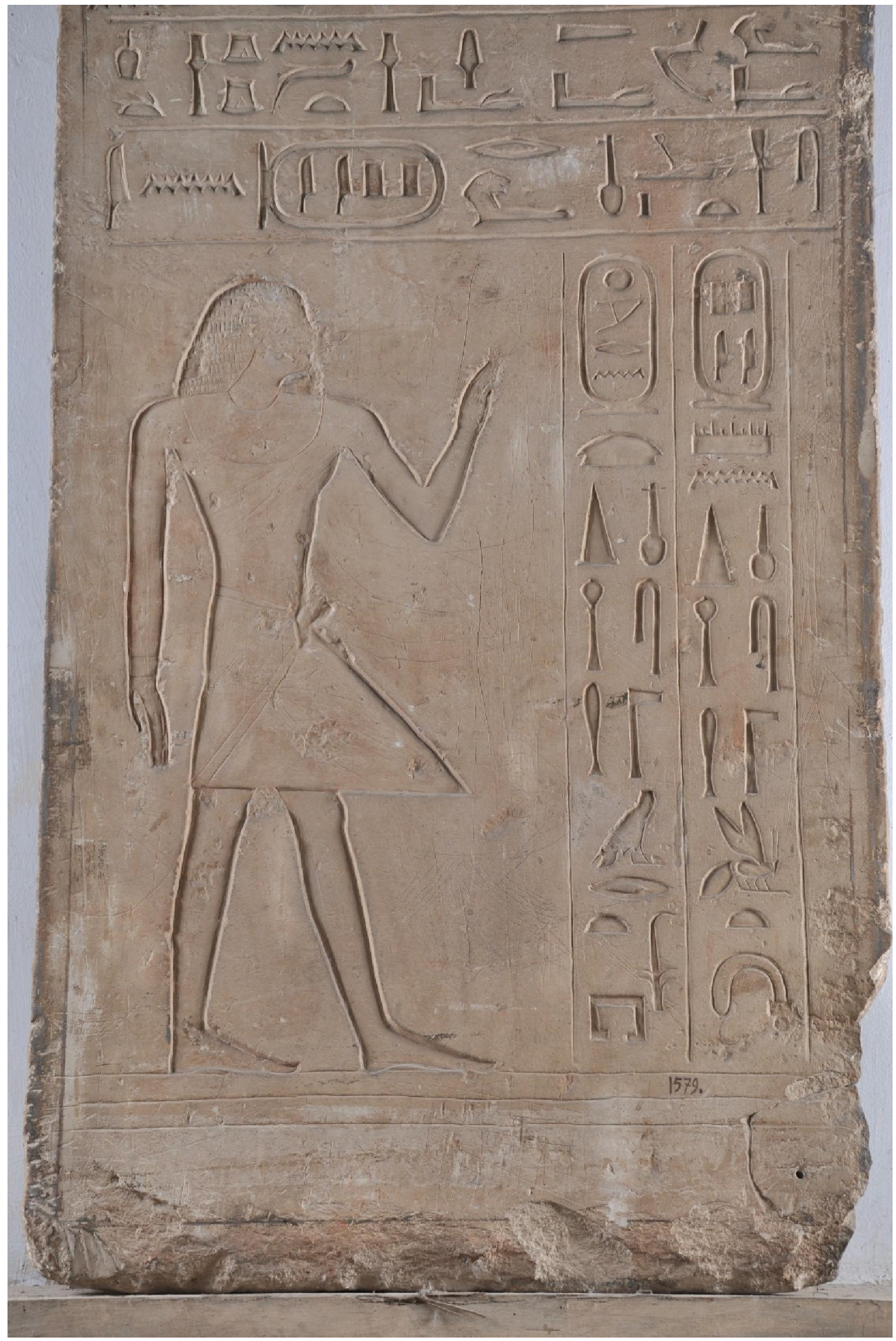




\section{Endnotes:}

(*) I am very grateful to Mrs. Sabbah Abdelrazek, the director General of Cairo Museum for her consent to publish this stela.

(1) Mariette, A., Abydos II, pl. 43 b.

(2) The usage of the incised or sunk relief, as a style of decoration of private stelae began by the reign of Ne-User-Re at least and gradually became the favourite style by the end of the fifth dynasty. El-Khadragy, M., "Two Old Kingdom false doors from Saqqara", p. 43.

(3) Brunner-Traut, E., "Gesten", p. 579 (3a).

(4) Brunner-Traut, E., "Gesten”, p. 579(3a).

(5) Bonnet, H., Ägyptische Tracht bis zum Ende des Neuen Riches, p. 25f, pl. IV, figs. 18-20; Staehelin, E., Untersuchungen zur agyptischen Tracht im Alten Reich, pl. XXI, fig. 10; Brier, B. and Hobbs, H., Daily Life of the Ancient Egyptian, 2nd edition, pp. 132-134.

(6) Green, L., "Hairstyles", p. 74.

(7) Russmann, E., "A Second Style in Egyptian Art of the Old Kingdom", p. 272 n. 32; Brovarski, E., "A Second Style in Egyptian Relief of the Old Kingdom”, p. 56 n. 48.

(8) Wb II, p.39 [4].

(9) Jones, D., Index II, p. 497:1862.

(10) Jones, D., Index I, p. 10:39.

(11) Jones, D., Index II, p. 724:2637; Gardiner, A., Egyptian Grammar, p. 509.

(12) Jones, D., Index II, pp. 725-726:2642.

(13) Jones, D., Index II, p. 892:3268.

(14) Jones, D., Index I, p. 321:1183.

(15) Jones, D., Index II, p. 935: 3448.

(16) Jones, D., Index II, p. 763:2775.

(17) Jones, D., Index II, p. 941:3471.

(18) Jones, D., Index I, p. 120:482.

(19) Ranke, H., Personennamen, p. 172:13.

(20) $\mathrm{PM} \mathrm{III}^{2} / 2$, pp. 427, 686; Kuraszkiewicz, K., "Two fragments of False - door frame of NyPepy from West Saqqara", p. 128 n.2.

(21) $\mathrm{PM} \mathrm{III}^{2} / 2$, p. 520; for names associated with kings Teti, Pepi and Merere, cf. Ranke, H., Personennamen, pp. 384, 385, 131, 132, 160, 161.

(22) Jones, D., Index II, p. 497:1862.

(23) Strudwick, N., Administration, pp. 133-134 (121); Piacentini, P., Scribes I, p. 300.

(24) CG 1439; CG 1575; Kanawati, N. and Abder-Raziq, M., Teti Cemetery III, p. 12(27).

(25) Wb II, p. 13[22]; Nims, Ch., "Some notes on the Family of Mereruka", p. 647 n. 45.

(26) Kanawati, N., Akhmim, pp. 117-119.

(27) Firth, C. and Gunn, B., Teti Pyramid Cemeteries I, p. 109 n.3; Nims, Ch., "Some notes on the Family of Mereruka", p. 647 n. 45; James, T. and Apted, M., Khentika, pp. 12-13.

(28) Fischer, H., Dendera, p. 97 n.442.

(29) Jones, D., Index I, p. 10:39.

(30) Helck, W., Thinitenzeit, p. 215.

(31) Petrie, W. et al., Medum, pls. 17, 20, 23 ; Borchardt, L., Das Grabdenkmal des Königs Ne-User-Re, p. 71.

(32) Strudwick, N., Administration, p. 310, tb. 30.

(33) Strudwick, N., Administration, p. 310, tb. 30.

(34) Davies, N. de G., Deir el-Gebrâwi I, pls. 8, 17; Brovarski, E., "Overseers of Upper Egypt in the Old to Middle Kingdoms", part 2, p. 22. 
(35) Gardiner, A., Egyptian Grammar, p. 478 (M1).

(36) Wb I, p. 79; Faulkner, R., CD, p. 20; Gardiner, A., Egyptian Grammar, p. 478.

(37) Gardiner, A., Egyptian Grammar, p. 454 (D36).

(38) Kaplony, P., Kleine Beiträge zu den Inschriften der Ägyptischen Frühzeit, pp. 58, 226; Jones, D., Index I, pp. 347-348 (1295-1296).

(39) Strudwick, N., Administration, pp. 56 (3), 75 (30), 96 (62), 97 (63), 99 (67), 100 (68), 101 (69), 115 (93), 121 (102), 154-155 (151); Brovarski, E., “Overseers of Upper Egypt in the Old and Middle Kingdoms", p. 25 (24) MHw.

(40) Strudwick, N., Administration, p. 121.

(41) Baud, M., Famille royale, p. 265.

(42) Y De Preter, D., "N.y-Ppy: A New Vizier of the Sixth Dynasty?", pp. 261-268.

(43) Who is dated according to Strudwick and Moreno Garcia by the end of the Fifth dynasty, Strudwick, N. Administration, pp. 140-141 (132); Moreno Garcia, J., Administration, pp. 142,149 [53]

(44) very similar to the order of the current stela.

(45) Jones, D., Index II, p. 724:2638.

(46) Helck, W., Beamtentiteln, p. 33.

(47) Gardiner, A., "The Mansion of Life and the Master of the King's Largess", p. 84.

(48) Gardiner, A., ., "The Mansion of Life and the Master of the King's Largess", p. 83; Haiying, Y., "The Famine Stela: A Source - Critical Approach and Historical Comparative Perspective", pp. 515-521.

(49) Gardiner, A., "The House of Life”, pp. 159, 175; Morenz, L., "Neues zum pr-anx - zwei Überlegungen zu einem institutionellen Zentrum der sakralen Schriftlichkeitskultur Altägyptens", pp. 77-81; Jasnow, R. and Zauzich, K., The Ancient Egyptian Book of Thoth I, pp. 33-34.

(50) Ward, W., Index, p. 9:22.

(51)This relationship appeared on the current stela as well as that of SSm-nfr IV.

(52) Jones, D., Index II, p. 724:2637.

(53) Gardiner, A., "The Mansion of Life and the Master of the King's Largess", p. 85.

(54) Gardiner, A., "The Mansion of Life and the Master of the King's Largess", p. 85.

(55) Helck, W., Beamtentiteln, p. 33, he also noted that the title was held by viziers in the middle of fifth dynasty.

(56) Jones, D., Index II, p. 725:2642.

(57) Strudwick, N., Administration, p. 162 (161).

(58) Gillam, R., Topographical, Prosopographical and Historical Studies II, p. 597 (165) ppyanx Hr-ib / Nfr-kA who is dated by the reign of Pepy II.

(59) Kanawati, N., El-Hawawish III, p. 8 (26), fig. 8, pl. 1.

(60) Gardiner, A., "The Mansion of Life and the Master of the King's Largess", p. 85.

(61) Junker, H., Giza II, pp. 161-162.

(62) Faulkner, R., "Reviews and Notices of Recent Publications", p. 167.

(63) Junker, H., Giza II, p. 162.

(64) Gardiner, A., "The Mansion of Life and the Master of the King's Largess", p. 85 n.3.

(65) Jones, D., Index II, p. 892:3268.

(66) Strudwick, N., Administration, p. 117 (96).

(67) Kanawati, N., Administration, p. 10.

(68) Strudwick, N., Administration, p. 310 tb. 30.

(69) This role is attested by the end of the Old Kingdom, Martin-Pardey, E., "Gedanken zum Titel Imi-r wpt”, p. 233; Eyre, C., "Weni’s Career and Old Kingdom Historiography”, p. 110. 
(70) This point of view was suggested by Fischer, Who believed that it was the lowest title in the titularies of Ip of El-Saff, cf., Fischer, H., The Tomb of Ip at El Saff, p. 21.

(71) Jones, D., Index I, p. 321:1183.

(72) Wb II, p. 256[16]; Gardiner, A., Egyptian Grammar, p. 450 (D3); Faulkner, R., CD., p. 132.

(73) for the names of wig cf., bbwt, Faulkner, R., CD., p. 82.

nbA, Faulkner, R., CD., p. 130.

For more names of wigs for men and women, cf.,

سميرة أحمد مدني: الثنعر المستعار في مصر القديمة حتى نهاية الدولة الحديثة، رسالة ماجستير غير منشورة، كلية الآداب،

(74) Wb II, p. 256 [16]; Faulkner, R., CD, p. 132.

(75) Borror, D., Dictionary of word Roots and combining Forms, p. 32; Hornblower, S. and Spawforth, A. (eds.), The Oxford Classical Dictionary, (diadem).

(76) Kerrn, E., "The development of the Ornamental "boatman's fillet" in the Old and Middle Kingdoms in Egypt", pp. 161-188.

(77) Jones, D., Index I, p. 323:1189.

(78) Jones, D., Index I, p. 323:1187.

(79) Who is dated according to Baer by the early reign of Pepy II, Baer, K., Rank and Title, pp. 156-157 [591].

(80) Who is dated by Brovarski by the early reign of Pepy II, Brovarski, E., "Overseers of Upper Egypt in the Old to Middle Kingdoms", p. 28 (42).

(81) Who is also dated by Brovarski by the early to Middle reign of Pepy II, Brovarski, E., "Overseers of Upper Egypt in the Old to Middle Kingdoms", p. 24 (12).

(82) Strudwick, N., Texts from the Pyramid Age, pp. 357-358; Blackman, A., Meir IV, pls. 4, 4a; Brovarski, E., "Overseers of Upper Egypt in the Old to Middle Kingdoms”, pp. 24, 28 $(12,42)$.

(83) Fischer, H., Varia Nova, p. 75, who preferred the reading Mn-nfr-Ppy rather than PpyMn-nfr.

(84) Jones, D., Index II, p. 932:3438.

(85) for the reading of this title cf. Jones, D., Index II, p. 941:3471, but the researcher separates the reading of the current title away from the title below imy-r pr nswt.

(86) Kaplony, P., “Totenpriester”, pp. 679-680; Roth, A., Egyptian phyles, pp. 91-92.

(87) Muhs, B., Egyptian economy, p. 43.

(88) Muhs, B., Egyptian economy, p. 43.

(89) Muhs, B., Egyptian economy, p. 43.

(90) Jones, D., Index II, p. 763:2775.

(91) Fischer, H., Egyptian Titles, pp. 77, 86.

(92) Emery, W., Archaic Egypt, p. 75.

(93) Strudwick, N., Administration, p. 310.

(94) Uphill, E., “The Office sDAwty bity”, p. 250.

(95) For example cf. in Sheikh Said, Davies, N. de G., Sheikh saïd, pp. 24, 27, 30. Also in

Deir el Gebrawi cf., Davies, N. de G., Deir el Gebrâwi I, p. 9; II, pp. 1,2,33.

(96) Uphill, E., "The office sDAwty bity", p. 250.

(97) Murray, M., Index, pp. 59-61.

(98) Urk I, p. 102:3.

(99) Urk I, p. 102:3.

(100) Fischer, H., Varia Nova, p. 2; Jones, D., Index I, p. 120:482.

(101) For the offices of the palace, cf. Helck, W., "Palastverwaltung", pp. 647-651; Y De Preter, D., "N.y-Ppy: A New Vizier of the Sixth Dynasty?”, p. 261, 268. 
(102) It was held in Saqqara by \#nty-kAi / ixxi, Strudwick, N., Administration, p. 125 (109), also in Sheikh Said by CHwty-nxt, LD, Abb II, 113e, and I'm-Htp, Davies, N. de G., Sheikh saïd, pls.29-30.

(103) Fischer, H., "Four Provincial Administrators at the Memphite Cemeteries", pp. 26-34; Fischer, H., Dendera, pp. 69, 129, 201-202.

(104) Baer, K., Rank and title, p. 241[225], who suggested a wide range for Ni-Ppy from the reign of Merenre to the end of the Eighth dynasty.

(105) The title sHD Hm(w)-nTr was attested in the Middle Kingdom with both gods' temples, Ward, W., Index, p. 154:1328 (wp-wAwt), p. 154:1330 (@r of Nekhen); and the mortuary temples of the pyramids as the Old Kingdom cf., Ward, W., Index, pp. 154-155:1327, 1329; Fischer, H., Egyptian Titles, p. 26:1328a.

(106) Lapp, G., Die Operformel des Alten Reiches, pp. 154-194 §263-326. The formula of addressing the living appears at the end of the fourth dynasty, it was very concise and asked those who could see the inscription a simple prayer, Later the texts developed and the idea of sanction is introducted - in the tomb of $T$ f for example the address to the living is part of a vast address to visitors - as a reward the dead undertook to defend them before the tribunal of the great god and those who neglect his opinions would be punished in the same court, this threat is expressed in a prohibitive formula which forms the counterpart of the call to the living.

Sainte Fare Garnot, J., L'appel aux vivants, pp. 91-92.

At the beginning of the fifth dynasty, these addresses continue to be in favor, at the same time appears the « Call to the Socialists », destined to strengthen the fidelity of the funeral priests who were promised important advantages in case they fulfilled their duties carefully, at the same time the formula took new forms and was enriched by the famous invocation : «O, you who live upon the earth, to which he owes his name », the gift of offerings was frequently solicited, the idea of retribution was modified; the favors of the king, the affection of the gods and the granting of privileges were the rewards reserved then for the living. Sainte Fare Garnot, J., L'appel aux vivants, p. 92.

(107) Urk I, pp. 122 (13-15), 186 (14), 187 (4); Edel, E., "Untersuchungen zur Phraseologie der ägyptischen Inschriften des Alten Reiches", p. 77.

(108) Sainte Fare Garnot, J., L'appel aux Vivants, p. 92.

(109) Sainte Fare Garnot, J., L'appel aux Vivants, pp. 19-20.

(110) Saint Fare Garnot, J., L’appel aux Vivants, p. 93.

(111) Fischer, H., Orientation, p. 49.

(112) Müller, H., "Gebärden auf Denkmälern des Alten Reiches”, p. 63.

(113) Fischer, H., Orientation, pp. 48-50, figs. 49-51.

(114) This style began from the reign of Pepy I to the end of the Eighth dynasty, Russmann, E., "A Second Style in Egyptian Art of the Old Kingdom", pp. 269-279.

(115) This type of wigs predominated in reliefs of that period, Brovarski, E., "A Second Style in Egyptian Relief of the Old Kingdom", pp. 56, 83-84.

(116) The appearance of the broad collar and Jewelery in general was frequent in the reliefs of that period, Brovarski, E., "A Second Style in Egyptian Relief of the Old Kingdom”, p. 84.

(117) This feature is characteristic of the second Old Kingdom style and it was attested in the tomb of vizier Mereruka, cf. Brovarski, E., "A Second Style in Egyptian Relief of the Old Kingdom", p. 54. Whose tomb might be built at the end of Teti's reign or at the beginning of Pepy's I reign, Strudwick, N., Administration, p. 101 (68). 


\section{The Stela of Ni-Ppy of Abydos}

(118) Brovarski, E., “A Second Style in Egyptian Relief of the Old Kingdom”, p. 54, this ear setting was known in the reliefs of Nekhebu who is dated by the middle to late reign of Pepy I cf., Strudwick, N., Administration, p. 113 (90).

(119) PM III $2 / 2$, p. 427 (Who was buried in the pyramid complex of Pepy II), p. 680 (Who was buried in the west of pyramid of Pepy II).

(120) Fischer, H., "Some early monuments from Busiris in the Egyptian Delta", p. 22.

(121) Strudwick, N., Administration, p. 318; Brovarski, E., "False Doors and History: the Sixth Dynasty", p. 100.

\section{Bibliography:}

- Baer, K., Rank and Title in the Old Kingdom, The structure of the Egyptian Administration in the Fifth and Sixth Dynasties, Chicago, 1960.

- $\quad$ Baud, M., Famille royale et pouvoir sous l'Ancien Empire égyptien, vol. I, IFAO, Cairo, 1999.

- $\quad$ Blackman, A., The Rock Tombs of Meir, vol. IV, ASE 25, London, 1924.

- $\quad$ Bonnet, H., Ägyptische Tracht bis zum Ende des Neuen Riches, UGA ̈̈ 7, Hildesheim, 1964.

- $\quad$ Borchardt, L., Das Grabdenkmal des Königs Ne-User-Re, Leipzig, 1907.

- $\quad$ Borchardt, L., Denkmäler des Alten Reiches, (Ausser den Statuen), im Museum von Kairo, volume II, Berlin, 1964.

- $\quad$ Borror, D., Dictionary of word Roots and Combining Forms, California, 1960.

- Brier, B. and Hobbs, H., Daily Life of the Ancient Egyptians, second edition, London, 2008 .

- $\quad$ Brovarski, E., "False Doors and History: the Sixth Dynasty", in: M., Barta (ed.), The Old Kingdom Art and Archaeology, Prague, 2006.

- Brovarski, E., "A Second Style in Egyptian Relief of the Old Kingdom", in: S.E., Thompson and P., Der Manuelian (eds.), Egypt and Beyond, essays presented to Leonard H. Lesko, Brown, 2008.

- $\quad$ Brovarski, E., "Overseers of Upper Egypt in the Old to Middle Kingdoms”, ZÄS 141, part 2, 2014.

- $\quad$ Brunner-Traut, E., “Gesten”, LÄ II, Wiesbaden, 1977.

- $\quad$ Davies, N. de G., The Rock Tombs of Sheikh Saïd, London, 1901.

- $\quad$ Davies, N. de G., Rock Tombs of Deir el Gebrâwi, 2 vols., ASE 11-12, London, 1902.

- Edel, E., "Untersuchungen zur Phraseologie der ägyptischen Inschriften des Alten Reiches", MDAIK 13, 1944.

- $\quad$ El-Khadragy, M., "Two Old Kingdom false doors from Saqqara”, GM 174, 2000.

- $\quad$ Emery, W., Archaic Egypt, Baltimore, 1961.

- $\quad$ Eyre, C., "Weni's career and Old Kingdom Historiography”, in: C., Eyre, A., Leahy and L., Leahy (eds.), The Unbroken Reed, Studies in the Culture and Heritage of Ancient Egypt in Honour of A.F. Shore, London, 1994.

- $\quad$ Faulkner, R., "Reviews and Notices of Recent Publications", JEA 27, 1941.

- $\quad$ Faulkner, R., A Concise Dictionary of Middle Egyptian, Oxford, 1968.

- $\quad$ Firth, C. and Gunn, B., Teti Pyramid Cemeteries, vol. I, Cairo, 1926.

- Fischer, H., "Four Provincial Administrators at the Memphite Cemeteries", JAOS 74, 1954.

- $\quad$ Fischer, H., Dendera in the Third Millennium B.C. down to the Theban domination of Upper Egypt, New York, 1968.

- $\quad$ Fischer, H., "Some early monuments from Busiris in the Egyptian Delta", MMJ 11, 1976.

- $\quad$ Fischer, H., The Orientation of Hierogly

- $\quad$ phs: Reversals, MMA, NewYork, 1977. 
Fischer, H., Egyptian Studies III, Varia Nova, New York, 1996.

Fischer, H., The Tomb of Ip at El Saff, New York, 1996.

- Fischer, H., Egyptian Titles of the Middle Kingdom, A supplement to Wm. Ward's Index, $2^{\text {nd }}$ edition, New York, 1997.

- $\quad$ Gardiner, A., "The House of Life", JEA 24, 1938.

- Gardiner, A., "The Mansion of Life and the Master of the King's Largess", JEA 24, 1938.

- $\quad$ Gardiner, A., Egyptian Grammar, $3^{\text {rd }}$ edition, Oxford, 1982.

- Gillam, R., Topographical, Prosopographical and Historical Studies in the $14^{\text {th }}$ Upper Egyptian Nome, vol. II, Michigan, 1991.

- Green, L., "Hairstyles", in: D., Redford (ed.), The Oxford encyclopedia Ancient Egypt, vol. II, Oxford, 2001.

- Haiying, Y., "The Famine stela: a source - critical approach and historical - comparative perspective", in: C. Eyre (ed.), Proceedings of the Seventh International Congress of Egyptologists, OLA 82, Leuven, 1998.

- Helck, W., Untersuchungen zu den Beamtentiteln des Ägyptischen Alten Reiches, Glückstadt, 1954.

- $\quad$ Helck, W., "Palastverwaltung”, in: LÄ IV, Wiesbaden, 1982.

- Helck, W., Untersuchungen zur Thinitenzeit, ÄA 45, Wiesbaden, 1987.

- Hornblower, S. and Spawforth, A. (eds.), The Oxford Classical Dictionary, $3^{\text {rd }}$ edition, 2005.

- James, T. and Apted, M., The Mastaba of Khentika called Ikhekhi, ASE 30, London, 1953.

- Jasnow, R. and Zauzich, K., The Ancient Egyptian Book of Thoth: A Demotic Discourse on Knowledge and Pendant to the Classical Hermetica, vol. I, Text, Wiesbaden, 2005.

- Jones, D., An Index of Ancient Egyptian Titles, Epithets and Phrases of the Old Kingdom, 2 vols., Oxford, 2000.

- $\quad$ Junker, H., Giza II, wien und Leipzig, 1934.

- $\quad$ Kanawati, N., The Egyptian Administration in the Old Kingdom, Warminster, 1977.

- Kanawati, N., The rock tombs of El-Hawawish: The Cemetery of Akhmim, vols. III, Sydney, 1982.

- $\quad$ Kanawati, N., Akhmim in the Old Kingdom, ACE 2, Sydney, 1992.

- $\quad$ Kanawati, N. and Abder-Raziq, M., The Teti Cemetery at Saqqara, vol. III, The Tombs of Neferseshemre and Seankhuiptah, Warminster, 1998.

- Kaplony, P., Kleine Beiträge zu den Inschriften der Ägyptischen Frühzeit, ÄA 15, Wiesbaden, 1966.

- $\quad$ Kaplony, P., “Totenpriester”, LÄ VI, Wiesbaden, 1986.

- Kerrn, E., "the development of the ornamental "boatman's fillet" in the Old Kingdom and Middle Kingdom", AcOr 24, 1959.

- Kuraszkiewicz, K., "Two fragments of False-door frame of Ny-Pepy from West Saqqara", ET 19, 2001.

- $\quad$ Lapp, G., Die Opferformel des Alten Reiches unter Berücksichtigung einiger späterer Formen, Mainz, 1986.

- $\quad$ Lepsius, C., Denkmäler aus Aegypten undAethiopien, vol. IV, Nach den Zeichnungen der von Seiner Majestäl dem Könige von Preussen Friedrich Wilhelm IV nach diesen Ländern Gesendeten und in den Jahren 1842-1845 ausgeführten wissenschaftlichen Expedition, auf Befehl Seiner Majestäl, Herausgegeben und erläutert von C.R. Lepsius, Zweite Abtheilung, Denkmäler des Alten Reichs, Blatt LXXXII-CLIII Berlin.

- $\quad$ Mariette, A., Les Mastabas de l'Ancien Empire, G., Maspero (ed.), Paris, 1884.

- $\quad$ Martin-Pardey, E., “Gedanken zum Titel imi-r wpt”, SAK 11, 1984. 


\section{The Stela of Ni-Ppy of Abydos}

- Moreno Garcia, J., Etudes sur l'administration le pouvoir et l'idéologie en Egypte, de l'Ancien au Moyen Empire, Liège, 1997.

- $\quad$ Morenz, L., "Neues zum pr-anx-zwei Überlegungen zu einem institutionellen Zentrum der sakralen Schriftlichkeitskultur Altägyptens", GM 181, 2001.

- $\quad$ Muhs, B., The Ancient Egyptian economy, 3000-30 BCE, Cambridge, 2016.

- $\quad$ Müller, H., "Darstellungen von Gebärden auf Denkmälern des Alten Reiches", MDAIK 7, 1937.

- $\quad$ Murray, M., Index of Names and Titles of the Old Kingdom, BSAES 1, London, 1908.

- $\quad$ Nims, Ch., "Some notes on the family of Mereruka", JAOS 58, 1938.

- $\quad$ Petrie, W. et al., Medum, London, 1892.

- $\quad$ Piacentini, P., Les scribes dans la société égyptienne de l' Ancien Empire, vol. I, Les premiéres dynasties, les nécropoles memphites, Paris, 2002.

- $\quad$ Ranke, H., Die Ägyptischen Personennamen, vol. I, Glückstadt, 1935.

- $\quad$ Roth, A., Egyptian Phyles in the Old Kingdom, The Evolution of a system of Social Organization, SAOC 48, Chicago, 1991.

- $\quad$ Russmann, E., "A Second Style in Egyptian Art of the Old Kingdom”, MDAIK 51, 1995.

- Sainte Fare Garnot, J., L'appel aux vivants dans les textes funéraires égyptiens des origines à la fin de l'Ancien Empire, IFAO, Cairo, 1938.

- $\quad$ Sethe, K., Urkunden des Alten Reiches, vol. I, Leipzig., 1933.

- $\quad$ Staehelin, E., Untersuchungen zur agyptischen Tracht im Alten Reich, MÄS 8, Berlin, 1966.

- $\quad$ Strudwick, N., The Administration of Egypt in The Old Kingdom: the Highest Titles and their Holders, London, 1985.

- $\quad$ Strudwick, N., Texts from the Pyramid Age, R. Leprohon (ed.), Atlantas, 2005.

- Uphill, E., "The Office sDAwty bity", JEA 61, 1975.

- Ward, W., Index of Egyptian Administrative and Religious Titles of the Middle Kingdom, Beirut, 1982.

- $\quad$ Y De preter, D., "N.y-PPy: A New Vizier of the Sixth Dynasty?", SAK 31, 20 